\section{Effect of exposure to daylight and air on ethyl acetate used in the determination of 4-hydroxy- 3-methoxymandelic acid}

\section{R. J. FARRAND From the Department of Chemi- cal Pathology, Royal Infirmary, Sheffield}

When ethyl acetate, which has been exposed to daylight and air, is used for the extraction of 4-hydroxy-3methoxymandelic acid (V.M.A.) by the method of Pisano, Crout, and Abraham (1962), a decrease in the subsequent conversion of V.M.A. to vanillin is observed. This investigation was undertaken because low values in the determination were obtained with some batches of the ethyl acetate used.

\section{METHOD}

The method was that of Pisano et al. (1962) as described by Sandler and Ruthven (1963). 4-Hydroxy-3-methoxymandelic acid was obtained from Calbiochem (A Grade) and ethyl acetate A.R. (Analar) was used.

For the purpose of this investigation, an acidified aqueous solution of V.M.A., saturated with sodium chloride, was extracted with ethyl acetate $(30 \mathrm{ml}$.) which had been treated in various ways before use. This was followed by extraction of the V.M.A. from the ethyl acetate into M-potassium carbonate. The extract of V.M.A. was converted to 4-hydroxy-3-methoxybenzaldehyde (vanillin) by heating at $50 \mathrm{C}$. for 30 minutes together with $0.1 \mathrm{ml}$. of $2 \% \mathrm{w} / \mathrm{v}$ sodium metaperiodate solution, and, after cooling, $0.1 \mathrm{ml}$. of $10 \%$ w/v sodium metabisulphite solution was added. The volume was made up to $4 \mathrm{ml}$. with M-potassium carbonate, and the optical density of the vanillin in this solution measured at $\mathbf{3 6 0}$ $\mathrm{m} \mu$. The extraction into toluene, which is part of the procedure of Pisano et al. for purifying urinary extracts, was unnecessary in dealing with aqueous solutions and was omitted.

As a standard, V.M.A. was added direct to M-potassium carbonate and converted to vanillin without extraction. The optical density readings so obtained were regarded as being $100 \%$ values in assessing loss of V.M.A. during the extraction.

Samples of ethyl acetate, treated as follows, were examined by the procedure.

(1) Taken direct from the supplier's bottle (dark brown Received for publication 14 July 1965. glass, kept away from light); (2) placed in a plain gla bottle, and kept on the laboratory bench exposed to daylight for varying periods; (3) placed in an identical plain glaş bottle, but kept in darkness for varying periods; (4) redistilled in nitrogen and placed in plain glass bottles air being excluded from some of the bottles and allowed to enter others. All were exposed to daylight.

RESULTS

Because of reduced conversion to vanillin, low mea $\vec{\Phi}$ recoveries of V.M.A. were obtained from all samples of ethyl acetate exposed to the combined action of air ancp daylight. The effect, which was not altered appreciably by prior redistillation of the solvent, tended to be moce pronounced and variable with time and increasing light intensity. The results are set out in the table, and were confirmed using ethyl acetate of a different quality (special grade for spectroscopy, B.D.H.) Other experi ments showed that, when recovery of V.M.A. was low this was not due to failure of the ethyl acetate to extract V.M.A. from the acidified aqueous solution, nor to failure of the potassium carbonate solution to extrat V.M.A. from the ethyl acetate.

TABLE OF RESULTS

\begin{tabular}{|c|c|c|}
\hline Ethyl Acetate Used & $\begin{array}{l}\text { No. of } \\
\text { Determinations }\end{array}$ & $\begin{array}{l}\text { Range o } \\
\text { Recovery } \\
\text { V.M.A. }\end{array}$ \\
\hline $\begin{array}{l}\text { (1) Direct from supplier's bottle } \\
\text { (2) Exposed to air and daylight }\end{array}$ & 20 & $85-110$ \\
\hline for $2 \mathrm{hr}$. & 3 & $55-60$ \\
\hline Exposed to air and daylight for $4 \mathrm{hr}$. & 3 & $40-45$ \\
\hline $\begin{array}{l}\text { Exposed to air and daylight for } \\
\text { one day }\end{array}$ & 10 & $6-95$ \\
\hline Exposed to air and daylight for & 10 & \\
\hline Exposed to air and very bright & 10 & \\
\hline daylight for $3 \mathrm{hr}$. & 2 & $14-24$ \\
\hline $\begin{array}{l}\text { daylight for } 1 \text { day } \\
\text { (3) Exposed to air in darkness for }\end{array}$ & 2 & $85-95$ \\
\hline $\begin{array}{l}1 \text { to } 10 \text { days } \\
\text { (4) Redistilled in nitrogen, exposed }\end{array}$ & 5 & $90-110$ \\
\hline $\begin{array}{l}\text { to light and air for } 2 \text { to } 10 \text { days } \\
\text { Redistilled in nitrogen, exposed to }\end{array}$ & 5 & $15-55$ \\
\hline $\begin{array}{l}\text { light with air excluded for } 2 \text { to } 10 \\
\text { days }\end{array}$ & 5 & $92-103$ \\
\hline
\end{tabular}

I wish to thank Dr. Arthur Jordan for encouragemet and advice.

REFERENCES

Pisano, J. J., Crout, J. R., and Abraham, D. (1962), Clin, chim, Ac

7, 285.
Sandler, M., and Ruthven, C. R. J. (1963). A.C.P. Broadsheet No. 